\title{
SECOND ORDER NONLINEAR EVOLUTIONARY SYSTEMS DRIVEN BY GENERALIZED MIXED VARIATIONAL INEQUALITIES
}

\author{
GuAngwang Su* And GuAngming XuE
}

Abstract. In this paper, we deal with the system formulated by abstract second order nonlinear evolution differential equations which are subject to a generalized mixed variational inequalities. Firstly, based on Ky Fan inequality theorem, we examine that the solution set of variational inequalities is bounded, closed and convex by getting rid of the rigid restriction of monotonicity. Afterwards, the existence of solutions for a class of nonlinear differential equation is discussed.

Mathematics subject classification (2020): 47H10, 49J40.

Keywords and phrases: Nonlinear system, evolution equation, variational inequality, mild solution.

\section{REFERENCES}

[1] N. T. V. AnH, T. D. KE, On the differential variational inequalities of parabolic-elliptic type, Mathematical Methods in the Applied Sciences, 40 (2017), 4683-4695.

[2] R. S. BuRACHIK, R. DíAZ Millán, A projection algorithm for non-monotone variational inequalities, Set-Valued and Variational Analysis, 28 (2020), 149-166.

[3] T. Cardinali, P. RubBioni, On the existence of mild solutions of semilinear evolution differential inclusions, Journal of Mathematical Analysis and Applications, 308 (2005), 620-635.

[4] B. C. Dhage, Multi-valued mappings and fixed points II, Tamkang Journal of Mathematics, 37 (2006), 27-46.

[5] K. FAn, A minimax inequality and applications, Academic Press, New York, 1972.

[6] H. O. FATTORINI, Second order linear differential equations in Banach spaces, North Holland Publishing, Amsterdam, 1985.

[7] L. Gasinski, Z. H. LiU, S. Migórski, A. Ochal, Z. J. Peng, Hemivariational inequality approach to evolutionary constrained problems on star-shaped sets, Journal of Optimization Theory and Applications, 164 (2015), 514-533.

[8] M. Kamenski, V. Obukhovs Kiı, P. ZeCCA, Condensing multivalued maps and semilinear differential inclusions in Banach spaces, Wlter de Gruyter: Berlin, New York, 2001.

[9] I. V. Konnov, An inexact penalty method for non-stationary generalized variational inequalities, Set-Valued and Variational Analysis, 23 (2015), 239-248.

[10] I. V. KonNOV, Regularized penalty method for general equilibrium problems in Banach spaces, Journal of Optimization Theory and Application, 164 (2015), 500-513.

[11] X. W. Li, Z. H. LiU, Z. S. MigóRS KI, Approximate controllability for second order nonlinear evolution hemivariational inequalities, Electronic Journal of Qualitative Theory of Differential Equations, 100 (2015), 1-16.

[12] Z. H. LiU, D. Motreanu, S. D. ZEng, Nonlinear evolutionary systems driven by mixed variational inequalities and its applications, Nonlinear Analysis: Real World Applications, 42 (2018), 409-421.

[13] Z. H. LiU, S. D. ZENG, D. Motreanu, Evolutionary problems driven by variational inequalities, Journal of Differential Equations, 260 (2016), 6787-6799.

[14] S. Migórski, A. A. KHAN, S. D. ZENG, Inverse problems for nonlinear quasi-hemivariational inequalities with application to mixed boundary value problems, Inverse Problems, 36 (2019), 1-19.

[15] S. Migórski, A. OChal, M. SofoneA, Nonlinear inclusions and hemivariational inequalities, Springer, New York, 2013. 
[16] S. Migórski, S. D. Zeng, A class of generalized evolutionary problems driven by variational inequalities and fractional operators, Set-Valued and Variational Analysis, 27 (2019), 949-970.

[17] S. MigóRSKI, S. D. ZENG, Mixed variational inequalities driven by fractional evolutionary equations, Acta Mathematica Scientia, 39 (2019), 461-468.

[18] S. D. ZenG, Y. R. BAI, L. GASISKI, P. Winkert, Existence results for double phase implicit obstacle problems involving multivalued operators, Calculus of Variations and Partial Differential Equations, 59 (2020), 1-18.

[19] S. D. ZENG, Z. H. LiU, S. MigóRs KI, A class of fractional differential hemivariational inequalities with application to contact problem, Zeitschrift Fr Angewandte Mathematik Und Physik, 69 (2018), $1-23$.

[20] S. D. Zeng, S. MigóRski, Z. H. LiU, J. C. YAO, Convergence of a generalized penalty method for variational-hemivariational inequalities, Communications in Nonlinear Science and Numerical Simulation, 92 (2020), 1-29.

[21] S. S. ZhANG, Variational inequalities and related problems (in Chinese), Chongqing Publishing Group, Chongqing, 2008. 